\title{
Determining the It-Based Islamic School Strategy (Case Study in Junior High School Plus Al Kautsar Malang, Indonesia)
}

\author{
Imron Arifin \\ Department of Educational Administration \\ Universitas Negeri Malang, Indonesia \\ imron arifin.fip@um.ac.id
}

\author{
Darmaji \\ Department of Educational Management \\ Universitas Negeri Malang, Indonesia \\ ajidarmaji64@gmail.com
}

\author{
Nur Amaliyah Hanum \\ Department of Educational Management \\ Universitas Negeri Malang, Indonesia \\ mkhanum9294@gmail.com
}

\begin{abstract}
The writing of this article aims to find out: (1) school profile; (2) vision and mission; (3) work program; (4) SWOT analysis; (5) strategy determination; (6) determination strategy; and (7) development program the Junior High School Plus Al Kautsar Malang. This article uses qualitative research methods with interview techniques. In order to provide quality education, strategic planning of educational institutions must be formulated thoroughly, starting from the national (macro) level, regional/departmental level (meso), to the institutional/school (micro) level. In line with the increasingly complex internal and external environment of school education institutions, the need for strategic planning and management is increasingly needed. This phenomenon needs to get a proactive response by trying to understand the new paradigm in the management of education that demands contextual studies in which the educational institutions/organizations operate.
\end{abstract}

Keywords: strategy determination, strategy management, junior high school

\section{INTRODUCTION}

The management of education applied in the internal environment of the school system is only part of the responsibility of the principal as an education manager. The principal as the school manager is responsible for leading and coordinating all staff in the school, both educators and education staff, by providing guidance and guidance for the implementation of their respective tasks.

Principals as managers of modern education today must be able to observe and respond to all challenges raised by the external environment both near and far. Near external environment is an environment that has a direct influence on the operations of educational institutions, such as the various potentials and conditions in the field of education that become the concentration of the school's own business, the competitive situation, the situation of educational customers, and graduates.

All of these have an effect on determining strategies that are expected to support schools in achieving their goals. The distant external environment is a variety of forces and conditions that emerge outside the near external environment including socioeconomic, political, national security conditions, technological developments, and global challenges. Indirectly affect the implementation of the education system in a school.

Internal and external environmental factors need to be anticipated, monitored, assessed, and included in such a way in the decision-making process of the principal. In decision-making principals are often forced to defeat the demands of internal and external activities of educational institutions in order to serve a variety of interests such as routine affairs, service, work must always be under the instructions or work guidelines set by the bureaucracy without considering the changing external needs of the organization, so that the decision- making process decisions are often not optimal in producing strategic decisions.

The impact of all that is the actual problem faced by educational institutions cannot be maximally resolved. Observations and assessments carried out simultaneously on the external and internal environment of educational institutions enable educational managers or principals to be able to identify various types of opportunities that exist to be able to formulate and implement various educational plans.

This overall design can be carried out through a process of action known as strategic management. Seeing the many factors that determine the success of education in schools required principals who are able to do strategic planning through strategic management. In order to provide quality education, strategic planning of educational institutions must be formulated thoroughly, starting from the national (macro) level, regional / departmental level (meso), to the institutional / school (micro) level.

In line with the increasingly complex internal and external environment of school education institutions, the need for strategic planning and management is increasingly needed. This phenomenon needs to get a proactive response by trying to understand the new paradigm in the management of education that demands contextual studies in which the educational institutions / organizations operate.

Thus, the guidance and improvement of the quality of junior high school graduates will cover the aspects of the workforce of principals by fostering management, curriculum, teaching and learning processes and guidance, infrastructure, management, and attitudes of the community and educational actors who will shape school performance. 


\section{METHOD}

The method used in this research is to use qualitative research methods with interview techniques. The interview is a person-to-person conversation (Ulfatin, 2014). The conversation is carried out by both parties, the researcher as the interviewer and the subject or respondent as the interviewee. In this study, the principal of Junior High School Plus Al Kautsar Malang us subject or respondent of researchers.

\section{RESULTS AND DISCUSSION}

Junior High School Plus Al Kautsar Malang has a vision and mission such as its vision: realized school graduates who believe, knowledgeable and pious charity, superior in performance and competitiveness in the field of science and technology and environmentally sound. While the mission include: develop attitudes, behaviors, and Islamic religious school; foster a spirit studied Islamic religion; carry out guidance and active learning, creative and fun, so that each student can develop optimally suit its potential; foster a spirit of excellence intensive and power competitiveness healthy for all people in schools both in academic and non-academic achievement and so on.

Principal of Junior High School Plus Al Kautsar Malang in achieving school goals has a plan or work program that must be done, which is covered in two parts of the program, namely the short-term work program and the medium- term work program. The short-term work program includes developing and enhancing the $4 \mathrm{~S}$ experiences (senyum / smiles, salam / greetings, sopan / polite, and santun / courtesy) to all school members, building and enhancing the experience of praying in the middle of the school, building and increasing the average value of UNAS targets in a sustainable manner, creating sports teams and art teams that are able to compete at the city, provincial and national levels, and so on. While the work program of the medium-term include realize the Olympic Team of math, science, and KIR are able to compete at the district level, provincial, and national level, increase the number of facilities/infrastructure and it empowerment that supports academic achievement and non-academic, increase the number of students who are active in Arabic and English, and so on.

The efforts of the head of Junior High School Plus Al Kautsar Malang in improving the quality of their schools must certainly be able to analyze the strengths, weaknesses, opportunities, and threats of the school (SWOT analysis). Its strength include: school environment secure a comfortable distance from the noise because it is located in the center of the housing, schoolbased IT, the only one public junior high school in Malang city who have obtained the title of School Adiwiyata National, shuttle service school, educators already understand S1 and S2 educational qualifications, learning the Quran and translating every day with mastery of tartil, ghorib, tajwid, translation and memorization of the Quran juz 29 and 30, and so on. Weaknesses include: locations in the middle of housing so that transportation is difficult to reach, facilities for supporting student activities are very limited due to limited school land, expensive school fees, and student input varying abilities.
The opportunity of Junior High School Plus Al Kautsar Malang is the community to send their children to schools based in religion, amidst the declining morality of children today which makes parents very hesitant to send their sons and daughters to primary education in public schools, religious schools or based on religion is still an alternative for parents to entrust their children's education. Threats of her, among others: in middle school junior high school quality so the school should work hard to be able to compete and government establish a free school to junior high school, so many parents send their children to public schools while school fees at Junior High School Plus Al Kautsar Malang is expensive.

Based on the results of the SWOT analysis above, it can be interpreted that Junior High School Plus Al Kautsar Malang has considerable strength followed by sufficiently open opportunities that are identified (S-O). In this position, the right strategy for Junior High School Plus Al Kautsar Malang is to be aggressive, because schools have the opportunity to continue to develop more advanced and excel among state schools. This is evidenced by the increasing number of students each year and the means and infrastructure for learning that continues to grow.

Along with the demands and needs of the people of Malang in facing the Information Technology (IT), Junior High School Plus Al Kautsar Malang was established and prepared as an integrated and comprehensive IT-based school model with internet and intranet facilities in learning. Based on this premise, Junior High School Plus Al Kautsar Malang is prepared as an IT-based Islamic nuanced Integrated Education by providing various facilities and completing the education component. Program development in 2016- 2020 entered into two five-year period that includes target facilities and infrastructure, learning goal and financial target.

\section{Profile of Junior High School Plus Al Kautsar Malang}

This school has 14 teaching staff with qualifications of S3/S2 education as much as $10 \%, \mathrm{~S} 1$ 90\%, and 0\% Diploma, with all teaching according to their respective fields. This school is only in its second year and has 75 students grouped into 4 study groups, grouped by gender. This school has 12 classrooms and supporting facilities, canteen room, UKS, BK and library. The school also has a principal and guest room, a teacher's room, and an administration room. Other infrastructure is the teacher/student toilet, worship hall/guard room and guard post. For flag ceremony activities, the school has a large school yard and school sports activities utilizing the sports field and swimming pool facilities that have been provided by the housing sector and for parking vehicles the school has a parking area.

\section{Vision and Mission Junior High School Plus Al Kautsar Malang}

Amirullah (2015), an educational institution or large or even small organization must always have a vision and mission. Mission is a unique form of purpose that distinguishes it from other similar educational organizations or institutions by identifying the scope of its 
operations. In a mission statement usually describes things such as product characteristics, markets entered and the technology used. Hamdan (2001), vision is an important element in organizations as part of strategic planning. The vision of its existence is important because it reveals or states for what reason the organization exists, and where it will develop.

Vision is the ultimate goal of the school that is achieved in the long term. While the mission is a medium-term goal which is then normally specified in the school goals that must be achieved every year of school operations (Sukaningtyas, et. al., 2017). Before an educational institution or school determines the strategies that will be used in the effort to achieve goals, the school must have a vision and mission that has been previously determined, namely by clarifying the position of educational institutions in competition associated with the direction and objectives as Figure 1.

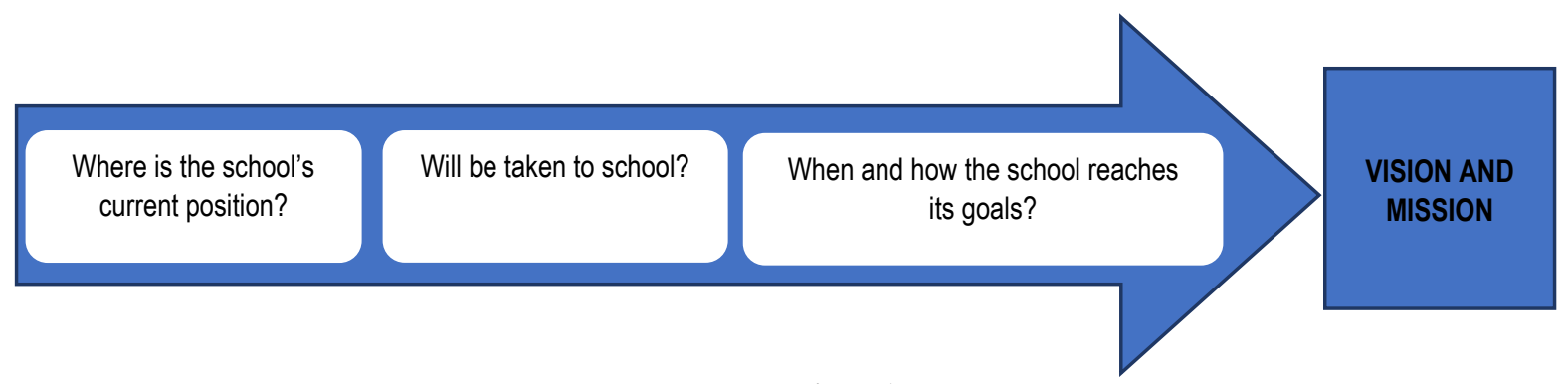

Figure 1

School Strategies and Direction (Amirullah, 2015)

The following is the vision and mission of Junior High School Plus Al Kautsar Malang needed before alternative strategies can be formulated, determined and implemented.

Vision

The realization of school graduates who believe, have knowledge, and do good deeds, excel in achievement and have competitiveness in the field of science and technology and environmentally friendly.

\section{Mission}

a. Developing the attitudes, behavior, and Islamic religion in schools;

b. Foster a spirit studied Islamic religion;

c. Carry out guidance and learning actively, creatively and fun, so that each student can develop optimally according to his potential;

d. Fostering a spirit of excellence intensively and healthy competitiveness to all school residents both in academic and non-academic achievements;

e. Creating a healthy, clean and beautiful school environment;

f. Encourage, help and facilitate students to develop their abilities, talents and interests, so they can be developed more optimally and have high competitiveness;

g. Develop life skills in every educational activity;

h. Developing an attitude of sensitivity to the environment;

i. Implement participatory management by involving all school members, school committees and stakeholders in decision making;

j. Realizing the school as an educational institution that has the trust of the community.

\section{Work Program of Junior High School Plus Al Kautsar Malang}

The work program is a plan of activities that will be carried out by the principal to achieve the objectives to be achieved. In other words, the work program in an educational institution is a reference to control and regulate all activities that occur at school. The work program of the Head of Junior High School Plus Al Kautsar Malang is divided into 2 parts, namely:

\section{Short Term Work Program}

a. Awakening and enhancing the $4 \mathrm{~S}$ experiences (senyum / smiles, salam / greetings, sopan / polite, and santun / courtesy) to all school members;

b. Build and enhance the experience of praying in the midday prayer at school;

c. Build and increase the average value of the UNAS target in a sustainable manner;

d. Create sports teams and art teams that are able to compete at the city, provincial and national levels;

e. Preparing and realizing the target number of graduates accepted at the favorite Senior High School (SHS or SLTA);

f. Build and increase the concern of school citizens for health, cleanliness and the beauty of the environment.

\section{Medium Term Work Program}

a. Creating a Mathematical, Natural Sciences, and KIR Olympiad team capable of competing at the City, Province and National level;

b. Increase the number of facilities/infrastructure as well as empowerment that supports the improvement of academic and non-academic achievements;

c. Increase the number of students who master Arabic and English actively;

d. Realizing the school as an educational institution calculated by the people of the city of Malang specifically and East Java in general;

e. Realizing the school as a referral school.

\section{SWOT Analysis of Junior High School Plus Al Kautsar Malang \\ Sonhadji and Huda (2014), SWOT analysis} (strengths, weaknesses, opportunities and threats) is an analysis of how to take advantage of opportunities, prevent threats, use strengths, and overcome weaknesses. 
SWOT Analysis (strengths, weaknesses, opportunities, and threats) of Junior High School Plus Al Kautsar Malang, among others:

\section{Strength}

1. The safe school environment is comfortable away from noise because it is in the middle of housing;

2. IT based school;

3. The only private junior high school in Malang that has been awarded the National Adiwiyata School;

4. There is a school shuttle service;

5. Educators already understand $\mathrm{S} 1$ and $\mathrm{S} 2$ education qualifications;

6. Learning the Qur'an and translating every day with mastery of tartil, ghorib, tajwid, translation and memorization of the Quran juz 29 and 30;

7. Small class with 25 students in class;

8. Schools that prioritize character values;

9. Have complete infrastructure for learning.

\section{Weakness}

1. Location in the middle of housing so that transportation is difficult to reach;

2. The supporting infrastructure for students' activities is very limited due to the limitations of school land;

3. Expensive school fees;

4. Student input is very diverse abilities.

\section{Opportunity}

The trend of the community to send their children to schools based in religion, in the midst of declining morality of children today which makes parents very hesitant to send their children to primary school level in public schools, religious or religious-based schools are still an alternative for parents to entrust their children's education.

\section{Threat}

1. Being in the middle of a quality public junior high school, so schools must work hard to be able to compete;

2. The government establishes free schooling for public junior high schools, so many parents send their children to public schools while the cost of education at Junior High School Plus Al Kautsar Malang is expensive.

\section{Strategy Determination}

Strategy management goes through several stages in its development. David (2009), the strategy management process consists of three stages including:

(1) strategy formulation, (2) application of strategy, and

(3) strategy evaluation. Strategy formulation includes developing a vision and mission, identifying external opportunities and threats of an organization, awareness of internal strengths and weaknesses, setting long-term goals, finding alternative strategies, and selecting or determining certain strategies to achieve goals.

Based on the above statement can be concluded that prior to an educational institution or organization to apply assess strategies to achieve the goals it must formulate, choose and define these strategies. Kurniawati (2017), before implementing a strategy to improve the quality of education, a school strategy formulation must be prepared in an effort to improve the quality of education which consists of three stages of formulation including: (1) formulation of school vision and mission, (2) formulation of school goals and objectives, and (3) determination of the school organization strategy. Following is the scheme of the strategy formulation process in Figure 2.

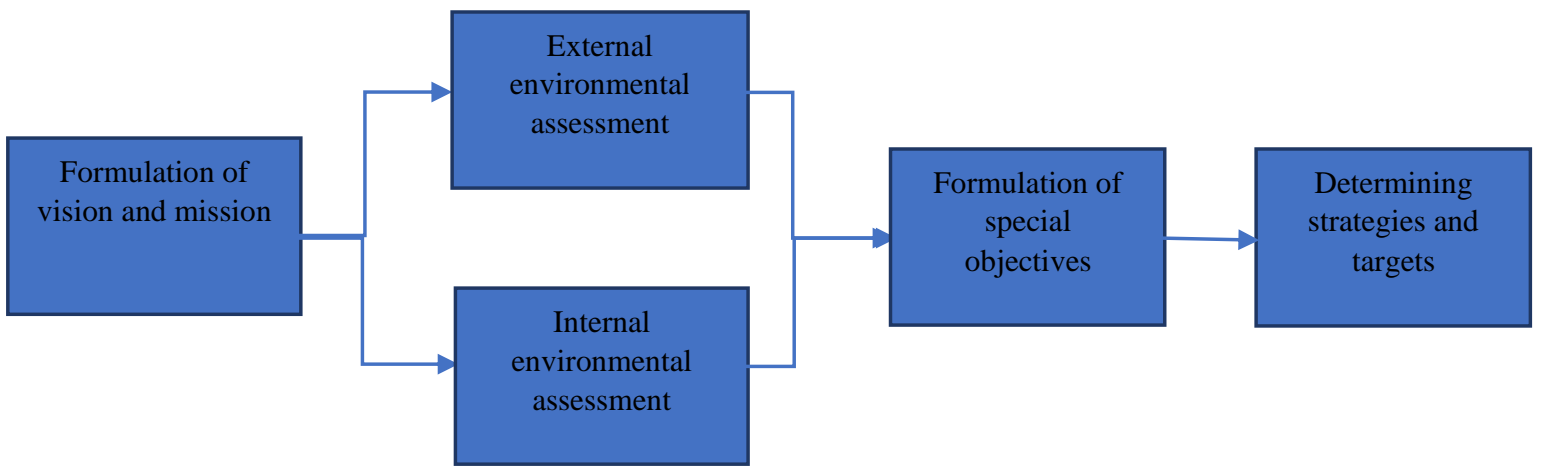

Figure 2

Strategy Formulation Process (Kurniawati, 2017)

While Amirullah (2015), to achieve strategic competitiveness and obtain high profits, an educational institution must analyze the external environment, identify opportunities and threats in the environment, determine which of internal resources and capabilities possessed are their core competencies, and choosing and determining the appropriate strategy to be applied (strategic formulation).

In order to provide optimal results for educational institutions, the formulation of strategies must be in accordance with product specifications, markets and marketing, organizational resources (financial or noneconomic) and technology. The wrong set of strategy formulations will have an adverse impact on the educational institution, so that the management or the principal must really understand and pay close attention to any possibilities that will occur.

\section{Determination of Junior High School Plus Al Kautsar Malang Strategy}

Based on the results of the SWOT analysis above, it can be interpreted that Junior High School Plus 
Al Kautsar Malang has considerable strength followed by sufficiently open opportunities that are identified (S-O). The following is an overview of the positions and strategy choices in Figure 3.

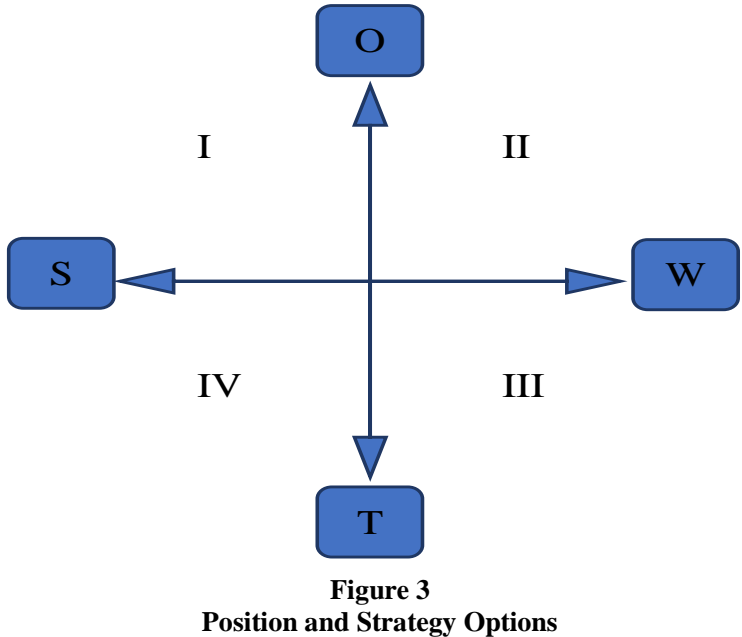

Development Program of Junior High School Plus Al Kautsar Malang

Along with the demands and needs of the people of Malang in facing the Information Technology (IT), Junior High School Plus Al Kautsar Malang was established and prepared as an integrated and comprehensive IT-based school model with internet and intranet facilities in learning. So that SMP Plus AlKautsar Malang is expected to be able to realize the level of efficiency and effectiveness in various aspects of educational activities, especially learning activities.

Junior High School Plus Al Kautsar Malang is also prepared as an integrated school, which aligns the needs of the world and the hereafter and develops emotional sensitivity and good intelligence (EQ and IQ) and mastery of vertical ruhiyah or Spiritual Quotient (SQ) towards students in the learning process balanced and quality, so that it is expected to be able to produce quality output academically, characteristic, spiritually and able to deliver its alumni to future progress which rests on 3 (three) concepts.

Based on this premise, Junior High School Plus Al Kautsar Malang is prepared as an IT-based Islamic nuanced Integrated Education by providing various facilities and completing the education component, which includes: physical facilities and infrastructure that are equipped with IT networks and other learning facilities, operational budget funds for school activities, recruiting educators and educators and students as a requirement for the sustainability of school activities accompanied by a hope of the realization of Al-Kautsar Junior High School as a superior school and get a positive response from the people of Malang and its surroundings.

As a new school with limited preparation to meet the National Education Standards (SNP) so there is still much to be done, both in the form of physical buildings and other educational equipment. Supporting facilities for learning activities that still need to be met, including: library space, UKS, Laboratory, BK and learning resource center. Recruit educators who meet the competency standards and educational qualifications. Educated educators are still not certified. So that the quality has still not reached the expected professional level. Educators still need guidance and strengthening their abilities to meet the standardized teaching staff. Likewise, in recruiting students faced with the problem of still not widely publicized schools and the tendency of the community to prioritize their choice in state schools, it has an impact on the quantity acquisition.

In terms of school management, Junior High School Plus Al Kautsar Malang also still has a lot of scope of work to be completed, which includes: implementation of content standards, graduation standards, process standards, and assessment standards, which are closely related to the organizer's policies. While the standard of teaching staff/education staff, facilities/infrastructure standards, school management standards, and financing standards relating to school management, teacher/school staff development must still be developed and improved. To realize the level of efficiency and effectiveness of school management in various aspects of educational activities, especially learning activities, the Junior High School Plus Al Kautsar Malang seeks to make efforts to develop curriculum in the framework of integrating Islamic values towards the realization of Junior High School Plus Al Kautsar Malang as an Islamic school. who excels in academics and non-academics and is at the forefront of innovation with a variety of work programs conducted by the Head of Junior High School Plus Al Kautsar Malang. The 2016-2020 Development Program enters the second five-year period which includes:

\section{Target Facilities and Infrastructure}

The target for the school development program is by continuing to complement the facilities and infrastructure, namely by completing all the existing needs in the participants 'learning space in the form of LCDs, air-conditioned rooms, quality of students' desks and benches, the addition of library book collections, the quality of facilities and infrastructure is a priority at stage 5 second year.

\section{Learning Goals}

School learning program activities for students continue to be enriched in order to provide positive experiences for students themselves. Various events were attended by schools both local and national scale. Improvement in teacher professionalism continues to be pursued by involving teachers in training programs, workshops and teacher involvement in teacher working groups and school principal organizations. Indicators of work that are expected of all students every day nothing without activities outside the classroom activities means in addition to learning, students really enjoy all school programs, their involvement is very enthusiastic proven all students involved in every school activity as well as support from parents no less important both to the school especially to their children.

\section{Financial Target}

School revenues continue to be pursued no increase in income, the allocation of use of financial 
resources are so far removed to hire many educators, then the cost of the development of the academic program, then complete the infrastructure to support learning and public relations for the promotion program of the school.

\section{CONCLUSION}

The vision of the Junior High School Plus Al Kautsar Malang is the shared ideals of the school community and all interested parties who are able to provide inspiration, motivation, and strength in carrying out the mandate of education. While the contents of Junior High School Plus Al Kautsar Malang contained measurable indicators of the stages of achievement during vision development. SWOT Analysis of Junior High School Plus Al Kautsar Malang is done by identifying and analyzing how Junior High School Plus Al Kautsar Malang utilizes opportunities, prevents threats, uses strengths, and overcomes weaknesses.

Strategy is a comprehensive plan for how schools carry out their mission objectively with planned management. The strategy management process consists of three stages including: (1) strategy formulation, (2) strategy implementation, and (3) strategy evaluation. In this position, the right strategy for Junior High School Plus Al Kautsar Malang is aggressive because the school has the internal strength and the opportunity to grow more advanced and superior in the public schools and other private schools.

\section{REFERENCES}

[1] Amirullah. 2015. Manajemen Strategi Teori-KonsepKinerja. Jakarta: Mitra Wacana Media.

[2] David, F. R. 2009. Strategic Management: Manajemen Strategis Konsep. Jakarta: Salemba Empat.

[3] Hamdan, Y. 2001. Pernyataan Visi dan Misi Perguruan Tinggi. Manajemen Komunikasi, e-Journal Unisba, 17(1), 1-9.

[4] Kurniawati, E. 2017. Manajemen Strategik Lembaga Pendidikan Islam dalam Meningkatkan Mutu Pendidikan Studi Kasus di Madrasah Aliyah Nahdlatul Ulama Gondang Sragen. Jurnal At-Taqaddum, 9(1), 1-8.

[5] Pearce, \& Robinson. 2009. Strategic Management: Manajemen Strategis Formulasi, Implementasi, dan Pengendalian. Jakarta: Salemba Empat.

[6] Sonhadji, \& Huda. 2014. Asesmen Kebutuhan, Pengambilan Keputusan, dan Perencanaan: Matarantai dalam Manajemen Pendidikan. Malang: Universitas Negeri Malang.

[7] Sonhadji, A. 2003. Modul Manajemen Strategik: Formulasi dan Implementasi Strategi. Malang: Program Pascasarjana Universitas Negeri Malang.

[8] Sukaningtyas, S., \& Sa'ud. 2017. Pengembangan Kapasitas Manajemen Sekolah dalam Membangun Pemahaman Visi dan Misi Pascasarjana Universitas Pendidikan Indonesia Bandung. Cakrawala Pendidikan, XXXVI(2), 1-9.

[9] Ulfatin, N. 2014. Metode Penelitian Kualitatif di Bidang Pendidikan: Teori dan Aplikasinya. Malang: Bayumedia Publishing. 